\title{
Pelatihan Manajemen Usaha Tani Dengan Fokus Petani Sebagai Entrepreneur Di Desa Ciwangi Kecamatan Blubur Limbangan Garut
}

\author{
Ryan Elfahmi ${ }^{1 *}$, Herry Suherman, Kemas Vivi Andayani, Agus, Hadyati Harras \\ Fakultas Ekonomi, Program Studi Manajemen, Universitas Pamulang \\ dosen01363@unpam.ac.id ${ }^{1 *}$
}

Received 20 April 2021| Revised 25 April 2021 | Accepted 26 April 2021

*Korespondensi Penulis

\begin{abstract}
Abstrak
Kegiatan pengabdian kepada masyarakat bertujuan untuk mengadakan Pelatihan Manajemen Usaha Tani dengan Fokus Petani sebagai Etrepreneur sebagai upaya meningkatkan pemahaman dan motivasi petani sebagai pelaku usaha di bidang pertanian di lingkungan desa Ciwangi Kecamatan Blubur Limbangan Kabupaten Garut. Metode yang digunakan dalam pelatihan menggunakan metode penyuluhan, pedampingan, diskusi dan workshop. Hasil yang diperoleh selama pelatihan, secara keseluruhan kegiatan pelatihan meliputi: materi, fasilitator, tempat pelatihan, dan konsumsi mendapat respon sangat baik dari seluruh peserta dan sangat membantu dan bermanfaat dalam meningkatkan pemahaman dan motivasi para peserta pelatihan tentang peran penting mereka sebagai entrepreneur yang diharapkan mampu meningkatkan kesejahteraan petani dan selanjutnya menggerakkan ekonomi dengan lebih baik di desa Ciwangi kecamatan Blubur Limbangan Kabupaten Garut.
\end{abstract}

Kata Kunci: Pelatihan; Manajemen; Entrepreneur; Petani.

\begin{abstract}
This community service activity aims to hold a Farmer Business Management Training with a Focus on Farmers as Entrepreneurs as an effort to increase understanding and motivation of farmers as entrepreneurs in agriculture in the Ciwangi village, Blubur Limbangan District, Garut Regency. The method used in the training uses the method of counseling, mentoring, discussions and workshops. The results obtained during the training, overall training activities include: material, facilitators, training places, and consumption received a very good response from all participants and are very helpful and useful in increasing understanding and motivation of training participants about their important role as entrepreneurs who are expected to be able to. improve the welfare of farmers and further drive the economy better in the village of Ciwangi, Blubur Limbangan district, Garut Regency.
\end{abstract}

Keywords: Training; Management; Finance; Competitiveness; UMKM.

\section{PENDAHULUAN}

\section{Analisis Situasi Permasalahan}

Dalam kegiatan Pengabdian Kepada Masyarakat kami melakukan kerjasama dengan Pemerintahan Desa Ciwangi Kecamatan Blubur Limbangan Kabupaten Garut. Dimana pemerintah desa memiliki fungsi penting untuk meningkatkan Sumber Daya Manusia dalam mengawal proses pembangunan khususnya di Desa Ciwangi. Desa Ciwangi memiliki 3 Dusun, 12 Rukun warga dan 44 Rukun Tetangga. Pemerintah desa tidak hanya mengawasi infrastruktur dan pembangunan tapi juga SDM harus ditingkatkan. Pemerintah desa bersama 
dengan semua lembaga terkait merencanakan pengawasan secara bersama sama. Pemerintah desa melalui aparatnya secara aktif melakukan diskusi dengan tokoh masyarakat, lembaga, organisasi dan masyarakat di wilayahnya. Aparat pemerintah desa yang diantaranya merupakan kepala daerah dalam lingkup yang lebih kecil (Kepala Dusun, Ketua RW dan Ketua RT) berperan aktif karena memahami secara detail mengenai lingkungannya masing-masing. Bersama-sama dengan masyarakat dan pemerintahan tingkat kecamatan, pemerintah desa melalui semua aparatnya mengawal pembangunan yang ada di lingkungan masing masing.

Pelaksanaan PKM kali ini terjadi pada masa pembatasan kegiatan sosial dalam memutus rantai penularan pandemi Covid 19. Sejak pertama diberlakukannya masa Pembatasan Sosial Berskala Besar (PSBB) yaitu tanggal 18 April 2020 (NOMOR HK.01.07 / MENKES / 249 / 2020) hingga saat ini masih terdapat celah dan kelonggaran di lapangan selama PSBB berlangsung. Pembatasan kegiatan sosial ini cukup berberdampak pada warga yang kesehariannya sebagai petani dan peternak baik skala mikro sampai menengah, pegawai pemerintah, karyawan swasta, dan pelayanan jasa yang penghasilannya didapatkan dengan cara bertemu langsung dengan para konsumen atau kliennya. Oleh karena itu, adanya pelatihan manajemen usaha tani secara komprehensif diharapkan dapat memberikan bekal pengetahuan yang memadai bagi pelaku usaha tani, dan fokus pada petani sebagai entrepreneur diharapkan dapat memberikan pemahaman lebih jauh tentang peran apa saja yang sebaiknya dijalankan petani dalam upayanya untuk meningkatkan kesejahteraan mereka sebagai petani dan meningkatkan pertumbuhan ekonomi di desa Ciwangi, selanjutnya dapat mengimplementasikan ke dalam usaha nyata yang ditekuni. Sehingga membantu pengembangan usaha tani dalam meningkatkan kemampuan ekonomi keluarga dan masyarakat.

\section{Permasalahan}

Dari hasil survey dan wawancara dengan Kepala Dusun dan Ketua RW bahwa permasalahan yang ada saat ini dan masih berlanjut, salah satunya penghasilan yang sangat minim dari bertani. Petani masih terus dihadapkan pada pertanyaan yang sama yaitu mau menanam apa yang akan memberikan hasil maksimal untuk menopang ekonomi keluarganya. Petani yang mayoritas cenderung memilih tanaman dengan periode panen yang lebih pendek membatasi petani dalam memilih tanamantanaman dengan nilai komersil yang tinggi. Selain itu, bagaimana bercocok tanam yang baik sudah merupakan keahlian mereka namun produktifitas yang tinggi dan kualitas yang bagus berdampak kurang secara ekonomi karena harga jual yang tidak sesuai harapan. Solusi yang diberikan terhadap permasalahan yang ada adalah perlu adanya penyuluhan untuk meningkatkan pemahaman yang lebih luas tentang peran petani sebagai entrepreneur agar para petani tidak terjebak dalam kerangka produksi saja tapi lebih luas kepada aspek-aspek lainnya. Motivasi para petani juga perlu ditingkatkan dalam penyuluhan agar para petani lebih bersemangat dengan menyadari peran penting mereka dalam lingkungan ekonomi yang lebih luas. Harapan lainnya adalah para petani mau keluar dari zona nyamannya untuk bisa melihat dan memanfaatkan banyak peluang yang selama ini mungkin belum mereka lirik.

\section{Tujuan Pengabdian kepada Masyarakat}

1. Memberdayakan sumber daya manusianya,

2. Membantu pelaku usaha tani untuk meningkatkan peluangnya dalam memperoleh penghasilan yang lebih baik.

3. Memberikan pengetahuan tentang manajemen usaha tani secara umum dan fokus pada peran petani sebagai entrepreneur. 
4. Memberikan pelatihan dasar manajemen aset dan mencari dan mengelola peluang-peluang terkait komoditas pertanian.

\section{Kerangka Pemecahan Masalah}

Alur kerja yang digunakan dalam menyelesaikan permasalahan yang dihadapi para petani di desa Ciwangi seperti ditunjukkan pada gambar berikut:

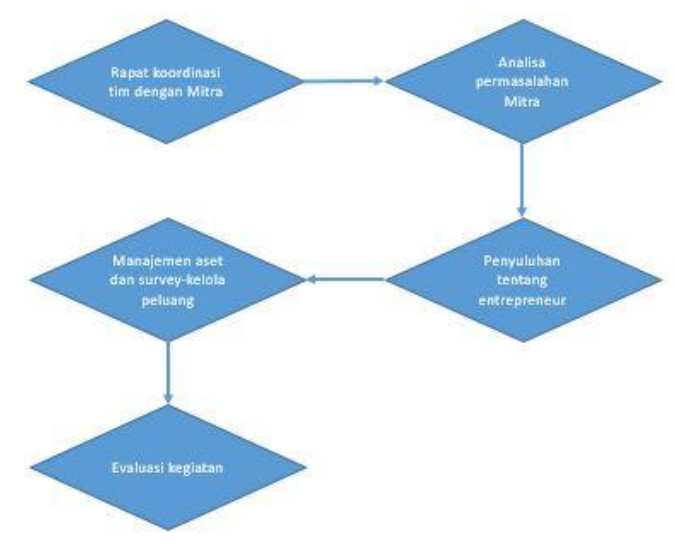

\section{Gambar1. Alur Penyuluhan Manajemen Usaha Tani Fokus Petani sebagai Entrepreneur}

Berdasarkan alur pada gambar di atas, ada tiga tahapan yang harus dilakukan dalam program pembuatan jurnal pendidikan. Tiga tahapan yang dilakukan meliputi:

1. Tahap Analisa Permasalahan Mitra

2. Tahap Penyuluhan tentang Entrepreneur

3. Tahap Pelatihan manajemen aset dan surveykelola peluang

\section{Realisasi Pemecahan Masalah}

Realisasi pemecahan masalah dalam pelatihan manajemen usaha tani fokus petani sebagai entrepreneur di Desa Ciwangi Kecamatan Blubur Limbangan Kabupaten Garut dengan tahapan sebagai berikut:

\section{Tahap Pra Pelatihan}

Kegiatan pra pelatihan ini dilakukan dengan koordinasi dengan mitra berkaitan dengan tujuan untuk menggali permasalahanpermasalahan yang dihadipi oleh mitra serta mencarikan solusi terbaik berdasarkan kondisi mitra.

2. Tahap Pelatihan

Kegiatan pelatihan/workshop merupakan kegiatan sosialisasi dan penyampaian materi tentang manajemen usaha tani secara umum dengan fokus pada peran petani sebagai entrepreneur dan survei-kelola peluang yang harus dipahami oleh para pelaku usaha tani. Sehingga kendala yang dihadapi dalam mengelola usaha taninya dapat ditemukan solusi dan jalan keluar pemecahannya. Selain itu peserta pelatihan akan diajarkan bagaimana mengelola aset (dasar) dan mencari peluang dan mengelola peluang tersebut agar terealisasi.

3. Tahap Pasca Pelatihan

Pada tahap ini, fokus kegiatan yang dilakukan dengan melakukan monitoring hasil pelaksanaan pelatihan bagi pelaku usaha tani, serta menyusun program lanjutan yang diperlukan untuk manajemen usaha tani.

\section{Kajian Pustaka Entreprenur}

Budaya kewirausahaan dalam sektor pertanian telah diakui sebagai faktor penting dalam proses pembangunan pertanian (Bergevoet et al., 2005; McElwee \& Bosworth, 2010). Pada beberapa negara di Eropa, pendidikan kewirausahaan pada petani ternyata memberikan kontribusi yang positif terhadap pengembangan kewirausahaan pada petani yang bertujuan untuk menumbuhkan pembangunan pertanian serta kesejahteraan petani (Marsden \& Smith, 2005).

Pertanian merupakan sektor yang sangat penting karena sangat dibutuhkan oleh semua kalangan masyarakat, namun saat ini pertanian masih belum diminati oleh kalangan generasi muda karena masih adanya pandangan bahwa pertanian adalah sektor yang tidak menjanjikan secara materi dan belum mampu memberikan jamian kehidupan yang layak bagi para 


\section{Ryan Elfahmi, dkk.: Pelatihan Manajemen Usaha Tani Dengan Fokus Petani Sebagai Entrepreneur Di Desa Ciwangi Kecamatan Blubur Limbangan Garut}

pelakunya di masa yang akan datang. Pertanian adalah sektor yang sangat heterogen, dimana para petani yang berusaha dalam suatu lingkungan yang kompleks dengan beragam permasalahan yang unik. Kondisi ini menjadi hambatan bagi petani dalam melakukan aktivitas kewirausahaan (Carter, 2003; McElwee, 2008a). Pengetahuan generasi muda yang terbatas mengenai sektor pertanian, juga menjadi penghalang bagi mereka untuk berkiprah dalam bidang pertanian.

Entrepreneur bisa diartikan sebagai pengusaha yang memiliki keberanian, kemandirian, serta ketrampilan sehingga meminimalkan kegagalan dalam usahanya. Entrepreneurship secara lebih luas didefinisikan sebagai proses penciptaan sesuatu yang berbeda nilainya dengan menggunakan usaha dan waktu yang diperlukan, memikul resiko finansial, psikologi, dan sosial yang menyertainya serta menerima balas jasa moneter dan kepuasan pribadi (Masykur Wiratno, 2001:2). Kemudian menurut Fadel Muhammad (Buchari Alma, 2001: 16), wiraswasta adalab orang yang memfokuskan diri pada peluang bukan pada resiko. Wiraswasta bukanlah pengambiJan resiko melainkan penentu resiko. Menurut Moh. As'ad (1991: 148) wirausaha harus memiliki karakteristik sifat kepribadian yang cukup menonjol yang secara kualitatif lebih dari kebanyakan manusia pada umumnya.

Ada dua karakter seorang entrepreneur, pertama entrepreneur sebagai creator yaitu menciptakan usaha atau bisnis yang benar-benar baru. Kedua, entrepreneur sebagai innovator, yaitu menggagas pembaruan baik dalam produksi, pemasaran, maupun pengelola dari usaha yang sudah ada sehingga menjadi lebih baik. Apabila seseorang terstimulus ide bisnisnya dari orang lain, kemudian menciptakan sebuah cara baru dalam produksi, pengemasan, dan penjualan, orang tersebut dapat disebut sebagai entrepreneur meskipun ia juga disebut seorang pedagang. Perbedaannya karena ada sesuatu yang baru diusahakan dengan membawa kemajuan signifikan terhadap usahanya, apakah itu perdagangan produk atau jasa. Menurut Riant Nugroho (2009) mereka yang disebut entrepreneur sejati adalah mereka yang mampu mengembangkan inovasi dalam bisnis sekaligus mampu memasarkan dengan baik. Menurut Bambang Trim (2010) setiap hari lahir anak-anak dengan bakat tertentu, diantara mereka ada yang memang memiliki kemampuan lebih dalam kecerdasan interpersonal, intrapersonal, dan kreativitas. Mereka menunjukkan rasa ingin tahu yang lebih terhadap usaha dan menciptakan sesuatu. Semua akan menjadi sis-sia ketika mereka tidak mendapat tempat untuk mengembangkan gagasan, ketrampilan, serta keingintahuannya.

\section{METODE}

Khalayak sasaran dalam pengabdian kepada masyarakat yaitu para pelaku usaha tani dan peternakan di lingkungan Desa Ciwangi Kecamatan Blubur Limbangan Kabupaten Garut yang berjumlah 25 orang peserta. Adapun waktu pelaksanaan pada hari Jum'at dan Sabtu, tanggal 2-3 April 2021, bertempat di Desa Ciwangi, Blubur Limbangan. Metode yang digunakan dalam penyuluhan manajemen usaha tani dengan fokus peran petani sebagai entrepreneur, Desa Ciwangi, Blubur Limbangan, Kabupaten Garut, menggunakan metode pedampingan, diskusi dan workshop manajemen aset, survei dan kelola peluang dalam bidang usaha tani.

\section{Metode Pelaksanaan Dalam Bidang Pengajaran}

Metode pendekatan pada program yang akan dilaksanakan adalah :

a. Melakukan pendataan pada mitra sampai sejauh mana pemahaman mitra tentang manajemen usaha tani dan peran sebagai entrepreneur sehingga dapat diketahui kondisi tentang pengetahuan mitra mengenai usaha yang dijalankan-nya.

b. Melakukan pengajaran pertama berupa 
teori tentang dasar-dasar manajemen dan entrepreneur.

c. Melakukan pengajaran kedua berupa teori dasar manajemen aset dan surveikelola peluang dalam bidang usaha tani

d. Mitra diberikan pendampingan dalam manajemen aset dan pengetahuan surveikelola peluang dalam bidang usaha tani.

\section{Metode Pelaksanaan Dalam Bidang Manajemen}

a. Berkoordinasi dengan mitra untuk proses belajar mengajar

b. Pembagian jadwal untuk proses belajar mengajar

c. Membuat tugas kepada mitra untuk menerapkan pengetahuan yang dimiliki dalam menerapkan manajemen aset dan survei-kelola peluang di bidang usaha tani.

\section{Metode Pelaksanaan dalam Fokus Entrepreneur}

a. Dengan pengetahuan yang dimiliki oleh mitra tentang entrepreneur diharapkan mitra mampu berpikir lebih ke depan dan lebih berani, mandiri, terampil dalam mengoperasikan usaha taninya.

b. Mampu melakukan berbagai survei dalam upaya untuk mencari peluang yang berpotensi untuk meningkatkan perkembangan usahanya dalam bidang pertanian.

c. Mampu mengelola peluang yang diperoleh dan merealisasikannya.

\section{HASIL DAN PEMBAHASAN Hasil}

Hasil pelaksanaan PKM diukur berdasarkan jawaban peserta pelatihan dengan tentang: materi pelatihan, fasilitator, tempat pelatihan dan sajian/konsumsi selama pelatihan yang diukur menggunakan penilaian skala 1 sampai 5 berikut:

Tabel 1. Skala jawaban responden pelatihan

\begin{tabular}{ll}
\hline Skor & Kriteria \\
\hline $4,21-5,00$ & Sangat Baik \\
\hline $3,41-4,20$ & Baik \\
\hline $2,61-3,40$ & Cukup \\
\hline $1,81-2,60$ & Kurang \\
\hline $1,00-1,80$ & Kurang Skali \\
\hline
\end{tabular}

Tabel 2. Penilaian Responden Terhadap Pelaksanaan Pelatihan

\begin{tabular}{|c|c|c|c|c|c|c|c|c|c|c|}
\hline No & Penilaian Kegiatan & 5 & 4 & 3 & 2 & 1 & $\mathrm{Jmh}$ & Skor & $\begin{array}{l}\text { Rata- } \\
\text { rata }\end{array}$ & Keterangan \\
\hline $\mathrm{A}$ & Materi Pelatihan & & & & & & & & & \\
\hline 1 & Jelas dan mudah diikuti & 7 & 15 & 3 & 0 & 0 & 25 & 104 & 4.16 & Baik \\
\hline \multirow[t]{2}{*}{2} & $\begin{array}{l}\text { Relevan dengan } \\
\text { objektivitas pelatikan }\end{array}$ & 8 & 15 & 2 & 0 & 0 & 25 & 106 & 4.24 & Sangat Baik \\
\hline & Sub Total_1 & 15 & 30 & 5 & 0 & 0 & 50 & 210 & 4.20 & Baik \\
\hline B & Fasilitator & & & & & & & & & \\
\hline 1 & Penguasaan materi & 9 & 14 & 2 & 0 & 0 & 25 & 107 & 4.28 & Sangat Baik \\
\hline 2 & Gaya penyampaian & 10 & 14 & 1 & 0 & 0 & 25 & 109 & 4.36 & Sangat Baik \\
\hline 3 & $\begin{array}{ll}\text { Kejelasan } & \text { dalam } \\
\text { penyampaian } & \\
\end{array}$ & 8 & 16 & 1 & 0 & 0 & 25 & 107 & 4.28 & Sangat Baik \\
\hline 4 & $\begin{array}{l}\text { Kemampuan dalam } \\
\text { menjawab pertanyaan }\end{array}$ & 11 & 9 & 5 & 0 & 0 & 25 & 106 & 4.24 & Sangat Baik \\
\hline \multirow[t]{2}{*}{5} & Penampilan & 12 & 10 & 3 & 0 & 0 & 25 & 109 & 4.36 & Sangat Baik \\
\hline & Sub Total_2 & 50 & 63 & 12 & 0 & 0 & 125 & 538 & 4.30 & Sangat Baik \\
\hline $\mathrm{C}$ & Tempat Pelatihan & & & & & & & & & \\
\hline 1 & $\begin{array}{l}\text { Kenyamanan dalam } \\
\text { belajar }\end{array}$ & 12 & 7 & 6 & 0 & 0 & 25 & 106 & 4.24 & Sangat Baik \\
\hline
\end{tabular}




\begin{tabular}{lllllllllll}
\hline No & Penilaian Kegiatan & 5 & 4 & 3 & 2 & 1 & Jmh & Skor & $\begin{array}{l}\text { Rata- } \\
\text { rata }\end{array}$ & Keterangan \\
\hline & Sub Total_2 & 12 & 7 & 6 & 0 & 0 & 25 & 106 & 4.24 & Sangat Baik \\
\hline D & Sajian/Konsumsi & & & & & & & & & \\
\hline 1 & Coffe break/snack & 12 & 8 & 5 & 0 & 0 & 25 & 107 & 4.28 & Sangat Baik \\
\hline 2 & Makan Siang & 13 & 7 & 5 & 0 & 0 & 25 & 108 & 4.32 & Sangat Baik \\
\hline & Sub Total_2 & 25 & 15 & 10 & 0 & 0 & 50 & 215 & 4.30 & Sangat Baik \\
\hline & $\begin{array}{l}\text { Kesimpulan Umum } \\
\text { Pelatihan }\end{array}$ & 102 & 115 & 33 & 0 & 0 & 250 & 1069 & 4.28 & Sangat Baik \\
\hline
\end{tabular}

5. Baik Sekali , 4. Baik, 3. Cukup, 2. Cukup, 1. Kurang Sekali

Berdasarkan hasil jawaban 25 responden dari 25 peserta pelatihan pada tabel di atas, diperoleh hasil sebagai berikut:

1. Materi pelatihan yang meliputi kejelasan materi, mudah diikuti dan relevan dengan obyektivitas pelatihan yang dilaksanakan diperoleh skor nilai 4,20 dengan kriteria baik karena terletak diantara skor 3,41 sampai 4,20.

2. Fasilitator pelatihan dalam hal penguasaan materi, gaya penyampaian, kejelasan materi, penampilan dan kemampuan menjawab pertayaan peserta diperoleh skor nilai 4,30 dengan kriteria sangat baik karena terletak diantara skor 4,21 sampai 5,00.

3. Tempat pelatihan dalam hal ini kenyamanan peserta selama peserta mengikuti pelatihan tergolong sangat baik dengan skor nilai 4,24 dan terletak diantara skor 4,21 sampai 5,00.

4. Sajian/konsumsi dalam hal penyediaan coffee break/snak dan makan siang peserta diperoleh skor nilai 4,30 dengan kriteria sangat baik karena terletak diantara skor 4,21 sampai 5,00.

Dari hasil keseluruhan pelaksanaan pelatihan manajemen usaha tani dengan fokus petani sebagai entrepreneur rata-rata keseluruhan diperoleh nilai 4,28 katagori pelatihan "sangat baik". Adapun urutan evaluasi pelaksanaan kegiatan pelatihan dari yang tertinggi hingga terendah meliputi: fasilitator dengan skor 4,30, sajian/konsumsi dengan skor 4,30, tempat pelatihan dengan skor 4,24 dan materi pelatihan skor 4,20 .

\section{Pembahasan}

1. Materi pelatihan yang diberikan kepada peserta baik karena materi disampaikan dengan jelas, mudah diikuti dan relevan dengan peserta.

2. Fasilitator pelatihan sangat baik dalam menguasai materi, cara/gaya penyampaian, kejelasan materi, penampilan dan kemampuan dalam menjawab permasalahan yang disampaikan oleh peserta.

3. Tempat pelatihan sangat baik, karena peserta merasa nyaman dalam mengikuti seluruh kegiatan pelatihan dari awal sampai akhir.

4. Konsumsi dan coffe break/snak yang disediakan sangat baik.

Adapun dokumentasi kegiatan pengabdian masyarakat seperti ditunjukkan pada gambar berikut:

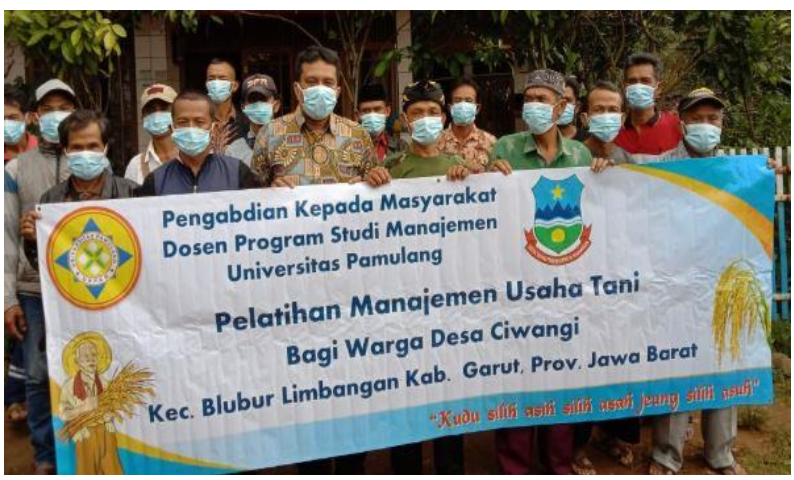

Gambar 1. Foto Bersama Narasumber dan peserta pelatihan 


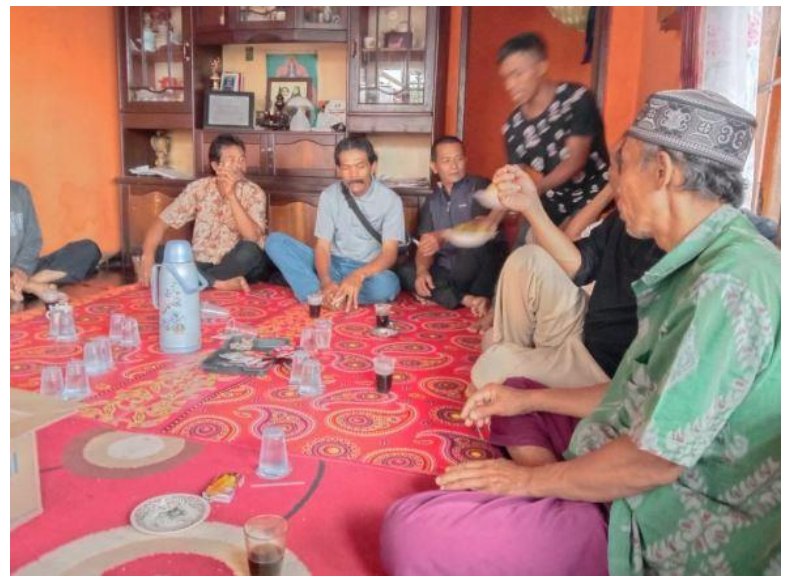

Gambar 2. Diskusi Materi Pelatihan-1

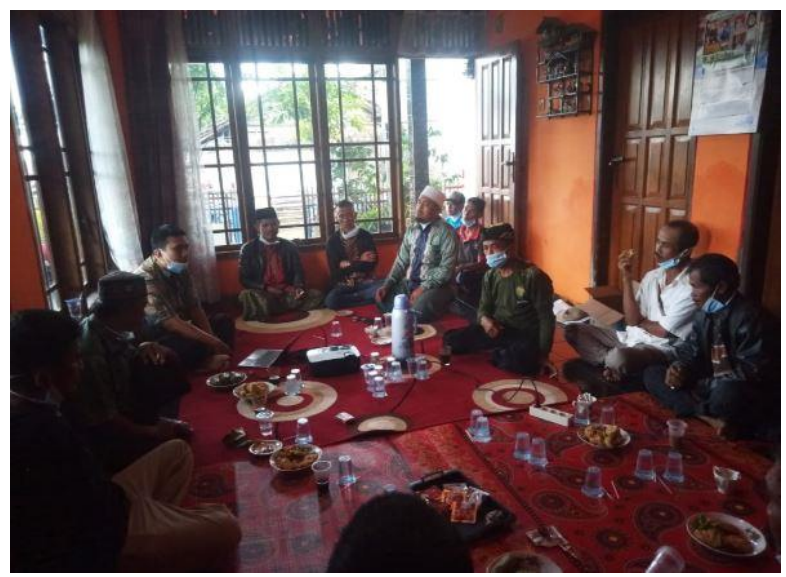

Gambar 3. Diskusi Materi Pelatihan-3

\section{SIMPULAN}

\section{Kesimpulan}

Kegiatan pengabdian kepada masyarakat yang dilakukan di lingkungan Desa Ciwangi Kecamatan Blubur Limbangan Kabupaten Garut sangat bermanfaat bagi masyarakat dalam meningkatkan pengetahuan dan motivasi yang pada akhirnya akan berperan penting dalam meningkatkan kemampuan ekonomi keluarga pelaku usaha tani. Oleh karena itu, kegiatan sejenis dapat dilaksanakan secara berkelanjutan dengan fokus-fokus lain yang dapat dikembangkan di lingkungan masyarakat sekitar Desa Ciwangi. Selain itu diperlukan adanya bantuan solusi untuk membantu pelaku usaha tani dalam menerapkan manajemen usaha tani secara lebih komprehensif dan modern sehingga akan meningkatkan efektifitas dan efisiensi usaha tani yang dikelola oleh masyarakat dalam upaya meningkatkan ekonomi masyarakat menjadi lebih baik lagi.

Secara keseluruhan kegiatan pelatihan yang meliputi: materi, fasilitator, tempat pelatihan, dan konsumsi mendapat respon sangat baik dari seluruh peserta. Sehingga pelatihan sejenis dapat terus dilaksanakan untuk membantu meningkatkan ekonomi pelaku usaha tani di Desa Ciwangi Kecamatan Blubur Limbangan Kabupaten Garut.

\section{Saran}

Perlu adanya pelatihan berkelanjutan bagi masyarakat di lingkungan Desa Ciwangi, Blubur Limbangan dengan beberapa masukan peserta pelatihan:

1. Jumlah peserta diperbanyak.

2. Kegiatan pelatihan sering dilaksanakan.

3. Materi yang diberikan lebih bervariasi, meliputi pelatihan manajemen operasi, manajemen sumber daya manusia, manajemen pemasaran dan manajemen keuangan.

4. Waktu pelatihan bisa ditambah/diperpanjang.

\section{DAFTAR PUSTAKA}

Bambang Trim. 2010. Kids On Business: Vaksin Wirausaha Untuk Ananda. Jakarta: Tiga Kelana.

Buchari Alma, Kewirausahaan, Penerbit C.V. Alphabeta, Bandung, 2001

Carter, S. L. (2003). Entrepreneurship in the farm sector: indigenous growth for rural areas. In Entrepreneurship in Regional Food Production, pp. 23-50. Norland Research Institute, Bodo, Norway.

Marsden, T. \& Smith, E. (2005). Ecological entrepreneurship: sustainable development in local communities through quality food production and local branding. Geoforum, 36(4), 440-451.

Masykur W., Pengantar Kewiraswastaan. Edisi Pertama. Cetakan ke dua.Yogyabrta: Penerbit BPFE. 200I 
McElwee, G., \& Bosworth, G. (2010). Exploring the strategic skills of farmers across a typology of farm diversification approaches. Journal of Farm Management, 13(12), 819-838.

Moh. As'ad., Psikologi Industri, Yogyakarta: Penerbit Liberty, 1991

Mukti, G. W., Andriani, R., \& Pardian, P. (2018). Transformasi Petani Menjadi Entrepreneur (Studi Kasus Pada Program Wirausaha Muda Pertanian Di Fakultas Pertanian Universitas Padjadjaran). Agricore: Jurnal Agribisnis Dan Sosial Ekonomi Pertanian Unpad, 3(2).

Nugroho, R. (2010). Memahami Latar Belakang Pemikiran Entrepreneurship Ciputra.

Nurseto, T. (2010). Pendidikan Berbasis Entrepreneur. Jurnal Pendidikan Akuntansi Indonesia, 8(2). 